\title{
MAKING CREATIVE INDUSTRIES POLICY: THE MALAYSIAN CASE
}

\section{Thomas Barker $^{*}$ and Lee Yuen Beng ${ }^{2}$}

${ }^{1}$ School of Modern Languages and Cultures, University of Nottingham Malaysia Campus, Semenyih, MALAYSIA

${ }^{2}$ School of Communication, Universiti Sains Malaysia, Pulau Pinang, MALAYSIA *Corresponding author: Thomas.Barker@nottingham.edu.my

Published online: 25 September 2017

To cite this article: Barker, T. and Y. B. Lee. 2017. Making creative industries policy: The Malaysian case. Kajian Malaysia 35(2): 21-37. https://doi.org/10.21315/km2017.35.2.2

To link to this article: $\mathrm{https} / / /$ doi.org/10.21315/km2017.35.2.2

\begin{abstract}
With the launch of the Dasar Industri KreatifNegara (DIKN) document in 2009, the creative industries have become a policy focus area for the Malaysian government in line with Wawasan 2020 (Vision 2020). By critically analysing the institutional background of the DIKN and creative industries policies implemented to date, this paper shows how the DIKN has been translated into subsequent policy. This paper argues that creative industries policy has largely narrowed to funding schemes and resulted in a proliferation of government agencies. Due in part to the legacy of the Multimedia Super Corridor (MSC) and Multimedia Development Corporation (MDEC), "digital" has increasingly come to be synonymous with "creative". We argue that this raises questions as to how the creative industries are perceived and supported and ultimately the meaning of creativity in the Malaysian creative industries policy context.
\end{abstract}

Keywords: Malaysia, creative industries, policy, film

\section{INTRODUCTION}

In Malaysia, the Dasar Industri Kreatif Negara (DIKN, National Creative Industry Policy) issued in 2009 is to date the only articulation of a comprehensive creative industries policy by the Malaysian government. Launched with much fanfare by former Minister Rais Yatim and signalling the government's new direction under Prime Minister Najib Razak, the DIKN was said to "empower the creative industries as a whole based on creativity and innovation, thus contributing to a high 
income economy and to uphold [sic] the nation's cultural heritage" (Rais, 2011). Issued by the Ministry of Information, Communication and Culture (Kementerian Penerangan Komunikasi dan Kebudayaan), the DIKN seeks to align the Ministry of Tourism and Heritage (now known as Ministry of Tourism and Culture Malaysia), The National Department for Culture and Arts (Jabatan Kebudayaan \& Kesenian Negara), National Film Development Corporation Malaysia (Perbadanan Kemajuan Filem Nasional Malaysia, FINAS), and Multimedia Development Corporation (MDEC), establishing a national creative industries platform. Each of these agencies had hitherto managed a smaller sub-sector of the newly-defined "creative industries". Aligning the work of these various agencies and ministries, the DIKN is designed to contribute to the ambitions of the government's Wawasan 2020 (Vision 2020), which aims to make Malaysia a developed nation by the year 2020.

This paper is a critical review of creative industries policy as it has been introduced since the DIKN. Although ambitious and comprehensive in its scope, the DIKN has diminished in prominence and is less instrumental in informing creative industries policy introduced in the years since 2009. By reviewing subsequent creative industries programmes and schemes, this paper argues that creative industries policy has narrowed, mostly resulting in funding schemes that lack the broad structural changes and infrastructure programmes proposed in the DIKN. These schemes proliferate bureaucratically as new agencies are established to implement and administer the above creative industries initiatives. Unanswered and unproblematised is the question of creativity itself which has largely been assumed but never discussed in the context of Malaysia's efforts to become a regional and international player in the creative industries.

\section{THE DIKN AS CREATIVE INDUSTRIES POLICY}

As with many creative industries policies around the world, the DIKN draws on the United Kingdom's Department of Culture Media and Sport (DCMS, 1998) definition of creative industries. Defining the creative industries as "Those industries which have their origin in individual creativity, skill and talent and which have a potential for wealth and job creation through the generation and exploitation of intellectual property," it identifies 13 sub-sectors. By contrast, the DIKN identifies 14 sub-sectors, dividing them into three categories: Creative Multimedia, Creative Cultural Arts, and Creative Cultural Heritage (see Table 1). In particular the DIKN makes explicit the emphasis given to digital media, which has become a focus of government agencies, especially MDEC. Significantly, the DIKN also emphasises the nation-building role of the creative industries and its potential to help foster harmony and social cohesion - a goal that often appears in creative industries policy documents. 
Table 1: DIKN classification of the creative industries

\begin{tabular}{|c|c|c|}
\hline $\begin{array}{c}\text { Industri Kreatif Multimedia } \\
\text { (Multimedia Creative } \\
\text { Industries) }\end{array}$ & $\begin{array}{c}\text { Industri Kreatif Seni Budaya } \\
\text { (Cultural Arts Creative } \\
\text { Industries) }\end{array}$ & $\begin{array}{c}\text { Industri Kreatif Warisan } \\
\text { Budaya (Cultural Heritage } \\
\text { Creative Industries) }\end{array}$ \\
\hline \multirow{2}{*}{$\begin{array}{l}\text { Penerbitan Filem dan TV } \\
\text { (Film and TV) }\end{array}$} & Kraf (Crafts) & Muzium (Museum) \\
\hline & Seni Visual (Visual Arts) & Arkib (Archives) \\
\hline \multirow{5}{*}{$\begin{array}{l}\text { Pengiklanan (Advertising) } \\
\text { Seni Reka (Design) } \\
\text { Animasi dan Kandungan } \\
\text { Digital (Animation and } \\
\text { Digital Content) }\end{array}$} & Seni Muzik (Music) & Pemulihan (Restoration) \\
\hline & Seni Persembahan & Pemuliharaan \\
\hline & (Performing Arts) & (Preservation) \\
\hline & $\begin{array}{l}\text { Penulisan Kreatif (Creative } \\
\text { Writing) }\end{array}$ & \\
\hline & $\begin{array}{l}\text { Fesyen dan Tekstil (Fashion } \\
\text { and Textiles) }\end{array}$ & \\
\hline
\end{tabular}

Source: Kementerian Penerangan Komunikasi dan Kebudayaan (2009).

According to the DIKN, Malaysia's creative industries contributed only $1.27 \%$ to national income, less than half of what comparable countries record (DIKN cities figures of $1 \%$ to $5 \%$ ), with the largest contribution from advertising. Accurate figures on the size and breakdown of Malaysia's creative industries are hard to come by. For example, World Intellectual Property Organisation (WIPO) estimates that the "core copyright industries" contributed 2.9\% to Malaysia's GDP and employed 518,200 people (WIPO, 2008). About 75\% of these jobs were in the Press and Literature, and Software and Databases categories. In 2014, MDEC calculated that companies registered in their Creative Multimedia Cluster employed 10,515 people. The Performance Management \& Delivery Unit (PEMANDU), under the purview of the Prime Minister, targets development in the Creative Content industry, aiming to create 10,422 jobs and contribute over RM3 billion (USD750 million) to national income by 2020. The fact that the MDEC and PEMANDU figures seem to contradict each other is indicative of how difficult it is to obtain accurate data on Malaysia's creative industries as a whole.

Since much of the emphasis is on the potential economic contribution of the creative industries, the DIKN advocates market-based improvements. This includes mainstreaming intellectual property, expanding training and employment opportunities, and developing overseas markets to export Malaysian-made cultural products. In terms of infrastructure, the DIKN advocates establishing a National Creative Industry Council (Majlis Industri Kreatif Negara) under the Kementerian Penerangan Komunikasi dan Kebudayaan and building new facilities, including a Malaysian Film Complex in the town of Dengkil (near the administrative capital Putrajaya), a National Music Complex, and a number of galleries, museums and libraries. Funding is also encouraged through incentives, loans, and grants 
as well as seeking foreign investment and new forms of subsidies for restoration and preservation activities in the heritage sector. Broadly, the strategy hopes to encourage public appreciation of the arts and culture to help expand the domestic market, improve quality, and raise awareness of the creative industries in Malaysia.

As has been noted with other creative industries policies around the world (Galloway and Dunlop, 2007), the twin goals of fostering social "harmony" and contributing to national income instrumentalise the creative industries. Cultural policy, which developed arts and culture, has traditionally contained goals such as fostering "national culture", but in the shift to "creative industries" there is an enhanced belief in the disruptive and transformative power of creativity and its ability to generate new sources of income (Oakley, 2009). In developed countries, the creative industries have been seen as a panacea for sluggish economic growth with attention placed on how the creative industries can contribute to employment and national income (Hesmondhalgh and Pratt, 2005). In Richard Florida's work on the creative class (Florida, 2002), attracting young creative workers is a way to encourage urban regeneration and create new forms of employment.

In a similar vein, the DIKN, like many creative industries policies, does not focus on how to develop and nurture creativity but assumes it is inherent in certain types of cultural products. This is evident in how the adjective "creative" (kreatif) appears in each of the three categories (see Table 1). If kreatif is removed, each of the categories is still coherent, suggesting that the addition of kreatif has not been adequately defined. Second, the use of kreatif is problematic in the "Cultural Heritage" category when used to bring together museums, archives, preservation (pemuliharaan) and restoration (pemulihan). It is highly debatable whether preservation and restoration are creative activities. Furthermore, if sites such as archives and museums are included, it is not clear why art galleries and libraries are not included. "Creative" therefore seems to cover everything from crafts to digital media, technical processes to fine arts, with little differentiation of the differences in skills, product, and creative input involved.

Despite the DIKN being formulated as a key policy document outlining how to develop the creative industries in Malaysia, in the years after its launch, it has faded from view, becoming less relevant to subsequent policy. Its launch was accompanied by a RM200 million (USD50 million) Creative Industry Fund (CIF), but three years later the Ministry of Information, Communication and Culture was renamed the Ministry of Communications \& Multimedia Malaysia (MCMM) and the DIKN website (www.industrikreatif.gov.my) disappeared. Although the DIKN document is available on the MCMM website, it no longer retains the prominence it once had. As the DIKN receded in prominence and relevance, creative industries policy has similarly devolved back to individual agencies and ministries. The result is that creative industries have lost the coherence and broad vision that the DIKN promised; as the next section shows, creative industries policy now comes from a 
number of agencies and through an array of policy initiatives which are multiple, complex, and often-overlapping.

\section{CREATIVE INDUSTRIES AGENCIES}

Malaysia's current policy response and environment for creative industries is somewhat muddled and confusing with multiple agencies, schemes, and programs. The Ministry of Communication \& Multimedia Malaysia (MCMM, also known as Kementerian Komunikasi dan Multimedia Malaysia) and PEMANDU, the Prime Minister's Office, which oversees the Economic Transformation Programme (ETP) whose broad goals are closely aligned with Wawasan 2020, implement most creative industries policy. MCMM and PEMANDU operate a number of different schemes and programmes, designed to encourage and support creative business and productions. Under MCMM sit three important agencies: Multimedia Development Corporation (MDEC), National Film Development Corporation Malaysia (Perbadanan Kemajuan Filem Nasional Malaysia, FINAS), and the Malaysian Communications and Multimedia Commission (MCMC). Composing the ETP are 13 priority sectors National Key Economic Area (NKEA), with the "Nurturing Malaysia's Creative Content" programme under the Communications Content and Infrastructure NKEA. Most of the creative industries policy has been in the form of funding or skills development schemes that have been administered by newly established agencies and bodies.

Although a range of agencies and ministries are identified in the DIKN, the most prominent and active of these is MDEC. MDEC was established in the 1990s to oversee the development of the Multimedia Super Corridor (MSC), an ambitious ICT programme. The MSC was envisaged as a kind of technology corridor, similar to Silicon Valley in California, which would extend 50 kilometres from Central Kuala Lumpur (KLCC) down to the administrative centre of Putrajaya, incorporating the new technology centre of Cyberjaya (King, 2008) and the Multimedia University (Ibrahim and Goh 1998: 9). Generous incentives were provided to local and foreign ICT and technology companies under the "MSC Status" scheme if they relocated operations to the Corridor. By promoting technology transfer and leveraging the nation's educated workforce, Malaysia sought to develop a domestic "information and knowledge-based" society and provide information, digital, and multimedia products and services to regional and global markets.

Although the MSC and MDEC were not created with the express purpose of developing the creative industries, entering the millennium this became one of their new areas of focus. MDEC shifted to developing digital content and multimedia including animation, special effects, digital content, and later mobile applications. Much of this followed the success of Les' Copaque Production's 
animation series Upin \& Ipin (2007) that received significant backing from MDEC. Further investment in "creative" companies came by recognising a new category of MSC status companies called Creative Multimedia Cluster (CMC). MDEC (2015) records 436 companies including more than 104 animation companies, 52 games companies, 100 companies in film, TV and VFX, and 54 in new media. ${ }^{1}$ Table 2 records the economic contribution of the companies in the CMC.

Table 2: Economic data pertaining to the Creative Multimedia Cluster

\begin{tabular}{cccc}
\hline Year & Revenue (billion RM) & Exports (million RM) & Jobs \\
\hline 2008 & 3.2 & 132 & 7,724 \\
2009 & 4.028 & 186 & 7,028 \\
2010 & 4.84685 & 255.98 & 8,086 \\
2011 & 6.07 & 363.46 & 9,183 \\
2012 & 6.99 & 490 & 11,070 \\
2013 & 6.39 & 430 & 10,170 \\
2014 & 7.1 & 500 & 10,515 \\
\hline
\end{tabular}

Source: MDEC (2014; 2015).

According to the MDEC data in Table 2, Malaysia's digital and multimedia sector is quite healthy, growing annually despite experiencing a decline in 2013. This sub-sector of the creative industries is already making significant contributions to export earning, revenue, and employment. Should this steady climb continue, it is projected that this cluster will generate over RM12 billion (USD3 billion) in revenue by 2020. It must also be noted that information in this table only pertains to companies accorded MSC status, which requires them to have at least $15 \%$ of their workforce composed of Knowledge Workers, and to develop or use multimedia technologies. According to MDEC, companies in the $\mathrm{CMC}$ are primarily engaged in multimedia or digital content creation, processing, packaging, and aggregation and delivery activities, or post production/animation/ virtual reality applications. However, with the focus on the use of technology, the question of "creativity" and the link to the creative industries remains unclear. The list of CSC companies includes many well-established media companies operating in Malaysia such as Media Prima, Al Jazeera, Astro Awani, and companies offering technology solutions and post-production services, but also wedding photography companies. ${ }^{2}$ It raises the question of whether these are in fact creative companies, or are simply called creative because they use digital technology.

Nevertheless, the CMC remains the only reliable source of data about creative industries companies in Malaysia. If related to the DIKN categorisations in Table 1, the CMC companies would be in the Creative Multimedia Industries 
column. Separately, PEMANDU under its "Nurturing Malaysia's Creative Content" programme expects the creative industries to contribute RM3,014 million (USD750 million) to national income and 10,422 jobs to be created by 2020 (PEMANDU, n.d.). PEMANDU targets an annual growth rate of $20 \%$ for content export - which according to Table 2 was exceeded in the years 2008-2012, but in 2012-2014 exports plateaued and have missed this 20\% growth target by a wide margin. How the PEMANDU projections fit with the MDEC data is not clear but the discrepancies suggest that the two agencies are not working closely together despite clear overlaps in their purviews.

MSC and MDEC have placed significant emphasis on developing digital and new media companies working in mobile apps and computer software development, animation, digital effects, and other forms of digital media. To that end, they have recorded some significant success, especially the support and promotion given to Les' Copaque Production (bought by The Walt Disney Company in December 2014) who developed the Upin \& Ipin animation series. Another successful MSC-status company was the Cyberjaya-based subsidiary of the California special effects company Rhythm \& Hues that employed more than 150 artists and personnel. Rhythm \& Hues went on to win an Academy Award for their work on The Life of Pi (2012), which included work from the Malaysian team. Both of these examples are touted as significant success stories for Malaysia. These examples also highlight how Malaysia is increasingly becoming well placed within the digital and online media industries that include games design and hosting, app development, and digital design for video games and computer animation.

Despite these success stories, current MSC and MDEC strategies are largely about developing private enterprises under MDEC's purview without addressing structural or regulatory issues. Such issues include a shortage of creative talent, long-term industry viability, state interference and arbitrary decision making, and whether the animation industry is viable without government funding (Ch'ng, 2015). It can be argued that Les' Copaque Production were successful because of the significant support from MDEC, but many other animation companies struggle to get domestic broadcast slots and monetise their intellectual property (Ch'ng, 2015). Moreover, the Rhythm \& Hues Academy Award was preceded by news that the parent company in the US filed for bankruptcy and had gone into financial administration. This was despite the company having outsourced much of its labour to cheaper studios in Malaysia, Taiwan, and India. The Malaysian office was kept open when the Chief Executive Officer was able to acquire the local office, renaming it Tau Films. In trying to move beyond being an out-sourcing location for manufacturing by promoting ICT related industries, the case of Rhythm \& Hues shows that Malaysia risks becoming an out-sourcing location for digital content. A local office of an international company is susceptible to decisions or events at the head office - usually in a "developed" nation - and may just as easily move 
operations to another country or jurisdiction if the company feels that operating costs and benefits are more favourable.

Similarly, the notion of creativity itself becomes problematic if, as in the case of Rhythm \& Hues, the Malaysian subsidiary of a California-based company is used to outsource technical tasks from its central office. This means that most of the decision-making process such as creative development, scripting, storyboarding, and directing would still occur in the United States. Although Malaysian artists working on the film may be highly skilled and capable of solving technical problems (for example texturing the tiger's fur in The Life of Pi), these roles are different compared to the decisions made in consultation with the film production company. Malaysia therefore risks positioning itself as a "content factory" where the mundane tasks related to texturing and rendering are conducted because of cheaper labour costs whereas the editorial and creative decision making process occurs overseas. Animation and digital effects work is celebrated domestically as a success story of creativity and appears to be creative because of the usage of computers and new media, but the actual creativity involved and the relationship between the Malaysian subsidiary and its US parent company needs to be interrogated. In effect it replicates the global outsourcing logic seen in manufacturing, reinforcing divisions between developed and developing nations, the exact scenario that Malaysia is trying to overcome in its Vision 2020.

The emphasis on digital technology can be comprehended not only as embracing new technologies and opportunities, but also as escaping the structures and limitations of legacy cultural industries such as film and television. Policymakers, businesses and entrepreneurs are able to start afresh in a "new" space without having to deal with established players and distributors such as media conglomerate Media Prima or the national film agency FINAS. Moreover, digital offers more global opportunities and is less encumbered by many of the content and distribution problems that film and television companies have to deal with such as negotiating with broadcasters or cinemas, or dealing with broadcast codes and regulations. Computer games or video effects can be made "culturally odourless" (Iwabuchi, 2002) as has already been done with Malaysian infographics website Piktochart (http://piktochart.com/) and app-based taxi booking service Grab (formerly MyTeksi). These are both Malaysian products but nothing from their design, content and function indicate their Malaysian origins. Products that are culturally specific often have limited markets, as is the case of Upin \& Ipin, which has only found export channels in Indonesia. 


\section{PROBLEMS AND CHALLENGES FACED IN THE IMPLEMENTATION OF DIKN}

Following the introduction of DIKN in 2009, a number of programmes targeting growth and development in the creative industries have been introduced. Such programmes include the RM200 million (USD50 million) Creative Industry Fund (CIF) introduced in 2010 for individuals and companies, especially those engaged in marketing their products in both local and global markets. The local animation industry was given priority for the funding due to its digital content and its potential to reach worldwide. PEMANDU then appointed local bank Bank Simpanan Nasional (BSN) to administer the loans. In November 2013, Fadhlullah Suhaimi Abdul Malek from PEMANDU described the scheme as "a leaking bucket" for the fund had been depleted as too many recipients had defaulted on payments (Economic Transformation Programme, 2013). The $80 \%$ of the recipients were from the film and television industry, including RM5 million (USD1.2 million) lent to Malaysian filmmaker U-Wei Haji Saari to finance his film Hanyut (Mahpar, 2010). Hanyut ended up costing a total of RM18 million (USD4.5 million) with most of its funding procured from government grants (Ect, 2015). Although the film was completed in 2012 it was only released in Malaysia in November 2016. It was released in Indonesia under the title Gunung Emas Almayer (Almayer's Golden Mountain) in November 2014 where it performed badly at the boxoffice. Although Hanyut may be an extreme example in terms of cost and history, questions are nevertheless raised about the disbursement of the CIF fund, viability of the projects funded, and financial oversight.

From 2011 to 2014, the MCMC administered another scheme called the Creative Industry Development Fund (CIDF) and allocated RM100 million (USD25 million) for television, mobile and web content development. When the CIDF ended in June 2014, a total of 44 projects had been funded with 39 launched (Malaysian Communications and Multimedia Commission, 2014). According to the closure notice of the CIDF found on the MCMC website, some of its funded projects included: TV documentary Lost over France: Malaysia's Unsung Hero, produced by 3Line Media and broadcast on the History Channel in 2013; and Knowsy Nina wants to Know, a cartoon series for four to six year old children produced by Avant Garde Studios. Both productions were also broadcast locally, with Knowsy Nina also televised on DAAI TV in Indonesia. The fund also provided capital for mobile apps and online websites that include the travel consultant website Islands of Malaysia (www.islands.com.my, www.myoutdoor.com); the now defunct www.wallpaper4share.com; and gigapan.com, a website providing technological solutions for high-resolution panoramic photos. All of these online 
projects are of dubious "creative" value, especially the wallpaper4share website which has been defunct since 2011 and was little more than a gallery of travel photographs linked to myoutdoor.com.

In 2012, Najib Razak announced an additional RM200 million (USD50 million) for the development of the creative industries in the annual national budget. This involved setting up MyCreative Ventures, a government investment arm to administer loans to creative industry businesses following the DIKN schema. Whereas banks are typically reluctant to provide loans to non-traditional businesses, MyCreative Ventures is designed to support creative industries businesses, which typically have a different cash flow and financial plan compared to more standard, bricks-and-mortar businesses. In February 2014, MyCreative Ventures announced investments totalling RM21 million (USD5 million) for 29 businesses (MyCreative Ventures, 2014) including fashion houses/designers, music, film, and crafts. By administering loans rather than giving grants, and with a board comprised of government, industry and academic figures, MyCreative Ventures aimed at avoiding problems encountered by the CIF and CIDF.

Another scheme called the Creative Industry Lifelong Learning Programme (CILLP) was introduced in 2012 under PEMANDU and FINAS as part of the Economic Transformation Programme (ETP). In part the rationale for CILLP states "although there appears to be enough talent to meet the demand, the industry has however expressed serious concern over the quality and skills of talent pool" (CILL, n.d.). The Creative Content Industry Guild (CCIG) an independent Civil Society Organization was created to lead the initiative. Inspired by the "lifelong learning" principle goals of improving knowledge, skills and competence, CCIG aims to increase relevant skills for creative content practitioners. There are four schemes in the program: the up-skilling and re-skilling scheme; internship scheme; attachment scheme; and creative skills certifications. The fields of study in the schemes mostly include producing and directing, scripting and screen adaptation, animation, games development, visual and special effects, sound effects and production support services. The scheme also includes a series of short courses and workshops. Successful applicants are then required to work in the creative multimedia industry for a minimum period of three years. According to one anonymous inside source, the attachment scheme that would send Malaysians overseas to work for a period of six months has to date only attracted three applicants.

The Creative Content Association Malaysia (CCAM) was also established under PEMANDU-ETP in 2012. Local content producers pay to become members of CCAM, which then acts as a forum for creative industry players to network, and as a promoter of "local content and creative services to overseas markets and international broadcasters" (CCAM, n.d.). Mohd Mahyidin Mustakim, who is the current CEO of Straits Films Sdn Bhd and former director of FINAS and Pesona 
Pictures, heads CCAM. The CCAM board members include representatives from Astro (Khairul Anwar Salleh, Vice President, Malay Language Business), and Media Prima (Kamal Khalid, CEO) and an Advisory Panel comprising officials from FINAS, RTM (Radio Television Malaysia), MDEC and ETP. Its role is to be a marketing body for a range of Malaysian-made digital, multimedia, and traditional media content at overseas markets, including sponsoring a programme of Malaysian films at the 6th Cambodia International Film Festival in 2015. The establishment-bias of its organisational structure and its embeddedness in existing government agencies puts into doubt its ability to represent smaller, independent, or alternative players in the creative industries. CCAM's flagship networking event KL Converge was held in August 2015, inviting forty buyers from around the world to match with local content producers.

Within the seven-year period since DIKN was introduced, a number of programmes and initiatives have been implemented to develop and cultivate the creative industries through funding or skills development. There however seems to be significant duplication, especially in the funding programmes, and a proliferation of bodies and agencies operating in the creative industries space. At other times, established bodies such as FINAS are partnered into often overlapping programmes either involving PEMANDU or MCMM. Moreover, there is a lack of detailed information about who has been receiving funding and whether the funding has been well utilised, raising questions of transparency and oversight (Malaysia Today, 2013). In the tabling of the National Budget 2015, another RM100 million (USD25million) was allocated for a Dana Industri Kandungan Digital (Digital Content Industry Fund) to be administered by the MCMM (Bernama, 2014). Despite over RM600 million (USD150 million) being budgeted for the creative industries over the past seven years and under seven different schemes, information about the effectiveness of funding remains scarce with many beginning to question the over-reliance on government funding for projects.

Although the DKIN places greater emphasis on digital media, the film industry remains one of the key industries in the constellation of a creative industries policy. The importance of filmmaking in Malaysia is evident through the establishment of FINAS in 1981, which was aimed at supporting and developing the film industry domestically and at exporting Malaysian films overseas (Perbadanan Kemajuan Filem Nasional Malaysia [FINAS], 2014). In order to achieve this, FINAS operates a number of support initiatives, which include a 30\% Entertainment Tax Rebate for local films, and a film-funding programme. In 2013, the Film-inMalaysia Incentive (FIMI) was introduced to provide foreign productions with a $30 \%$ cash rebate along with funding for feature film productions.

Up until 2010 local ethnic Chinese filmmakers found that their films did not qualify for the 30\% Entertainment Tax Rebate since the rebate was only available for films containing $60 \%$ of its dialogue in Bahasa Malaysia, the official national 
language. Films made in vernacular languages and dialects such as Cantonese, Mandarin, Tamil, Hokkien and even English would therefore not qualify for this rebate. The filmmaker behind the successful Ice Kacang Puppy Love (2010), Ah $\mathrm{Niu}$, challenged what he perceived as discrimination because although his film was not in Bahasa Malaysia, it was made in Malaysia by Malaysians. Only after FINAS was pressured by filmmaker protests in the local media did they change this criterion. According to then Minister of Information, Communication, and Culture Rais Yatim, a film would now be considered as "local" and qualify for the rebate if the film was subtitled in Bahasa Malaysia, at least half of the film is produced in Malaysia, and at least $51 \%$ of the film rights are owned by Malaysians. After the change in policy, Ice Kacang Puppy Love was awarded RM740,000 (USD180,000) in tax rebates (Lee, 2014). Whilst it is understandable that FINAS would want to uphold the usage of the national language in films, the manner in which the rebate was applied seemed to be discriminatory and unfair rather than supportive. It must also be noted here that this criterion was changed due to pressure and not FINAS realigning its policies for the DIKN.

Another effort at elevating the standard of filmmaking in Malaysia was through the building of Pinewood-Iskandar Studios in the southern state of Johor. The studios marked Malaysia's serious intention to become a regionally if not globally significant production location. Launched in December 2013 and including sound stages, Pinewood-Iskandar cost over USD170 million to build (RM550 million) and represented a joint-investment between the PinewoodShepperton company (UK) and Khazanah Nasional Berhad, the investment-holding arm of the Government of Malaysia. Pinewood-Iskandar also houses a number of production related services and Astro TV, also partly owned by Khazanah Nasional, utilises the studios. In addition, the Iskandar Malaysia Creative Industry Talent Development Program runs short courses in filmmaking for Malaysians aiming to develop their filmmaking skills (IMCITDP, http://www.iskandar-filmtraining.com.my/)

Netflix production Marco Polo inaugurated the Pinewood Studios, but in the years since only one feature film, Lost in the Pacific (2015), and four television productions by Astro have used the studios. In 2015 it was announced that the RM50 million (USD15 million) Mainland Chinese production Alien City ("Hollywood film," 2014) would be shot in Malaysia. More tellingly in 2015, a theatre production called P. Ramlee The Musical (2015) was performed to audiences in the studio spaces. Pinewood Iskandar's stated ambition of "becoming the center for international film production in Asia" (Pinewood Iskandar Malaysia Studios, 2014) has yet to be realised. Competing studios opened in Batam, south of Singapore, by Indonesian entrepreneur Mike Wiluan's Infinite Studios company have managed to attract work from Singaporean companies as well as the recent HBO Asia mini-series Halfworlds (2015). Infinite Studios has been able to attract 
much more work from the growing media hub in Singapore, and from local and international companies. What is broadly missing from the programmes and policy outlined above is a clear and systematic effort to reform and restructure the regulatory and institutional eco-system in which the creative industries operate. As the DIKN has largely been forgotten, the efforts by government agencies have narrowed to questions of funding and skills development. By contrast, the DIKN outlines a far broader range of policy areas including developing infrastructure, reforming broadcast and exhibition regulations, and strengthening intellectual property. None of these recommendations have been adopted. Instead, those in the creative industries operate under an ad-hoc regime of funding programmes that are often short-term and focused on bringing content to market, rather than strengthening the domestic market to help make local companies viable.

\section{CONCLUSION: SOLUTIONS AND RECOMMENDATIONS TOWARDS A CREATIVE ENVIRONMENT}

The Malaysian government has set itself the ambitious target of becoming a developed nation by 2020 as outlined in Wawasan 2020. Much of the emphasis in Wawasan 2020 is on economic factors - such as GDP per capita - but becoming developed also entails a range of other indicators related to quality of life and the operation of government. This would include having a strong and vibrant creative and cultural sector, supported by world-class institutions, support services and facilities, and a supportive policy environment. Whilst the Malaysian government has outlined a broad creative industries policy in the DIKN, in the years since its introduction it has featured less and less in creative industries policymaking and policy thinking. Instead, creative industries policy has largely been left to the MCMM and PEMANDU; the two are partner agencies and are often in competition with each other or overlapping in terms of scope. It remains the case that the creative space is still very fragile and contentious, especially considering the experiences in the film industry. As of Budget 2014, furthermore, it appears that the DIKN has disappeared altogether from the Malaysian government's policy platforms (Malaysia Today, 2013).

One thread that emerges from the Creative Industries direction adopted by the Malaysian government over the past decade is the emphasis on the Creative Industries as a technical and economic, rather than a social or cultural problem. In much policy "creative" is really a synonym for "digital", which not only extends the extensive work done by the MSC and MDEC since the 1990s, but also allows policymakers to focus on products and technologies rather than bigger questions related to censorship, regulation, and infrastructure. It also means that the social conditions of creativity - following the suggestions of Florida (2002) or the strategy 
of investing in education (Peck, 2005) - can be ignored in favour of technological solutions. Creativity is notoriously hard to legislate for, but certainly involves urban environments conducive to fermenting ideas and interaction, encouraging the creative class (Florida, 2002), and ensuring the educational system is open, dynamic, and teaching arts-based subjects (Peck, 2005). In Malaysia, on the other hand, "creative" often simply conflates with anything that involves digital technology or multimedia. Post-production for films, video effects, or animation studios may only be providing "grunt work" that require technical skills, but not so much the "creative" work including development and scripting. Instead, the emphasis in policy remains on providing grants and funding or on skills training, suggesting that all Malaysia's creative workers lack skills and money. This approach treats the creative industries as basic industries, seemingly misunderstanding the fact that creative industries involve culture, which cannot simply be produced and marketed in the same way as industrial products are.

Moreover, the focus on how much the creative industries contribute to national income instrumentalises creativity, rather than thinking about the broader arts and media environment from which that work emerges. Strong creative industries rely on a much larger arts and culture "scene" in which music, art, media, and so on give young people space to experiment and express themselves, allowing them to develop their skills and abilities before commercialising their ideas into a feature film or smartphone app, for example. Attention to either the broader eco-system of creativity or ways of encouraging more people to become creative in arts or business is missing from policy. So far, there seems to be little emphasis given to addressing possible problems in how creative industries are structured, regulated, or operate, and to broader questions about the educational system or urban planning.

To move forward at this point with a cohesive and broad creative industries policy seems to be a distant prospect. The enthusiasm for promoting and developing the creative industries has clearly waned over recent years as other political and economic issues have preoccupied the Malaysian government and its ruling party. Prone to politicisation, future creative industries policy would need to be quarantined from political interference and viewed as contributing to enriching cultural and community life, above communal allegiances and party politics. It would need to be based on a comprehensive understanding of the state of creativity in Malaysia, how the creative industries are faring, and what they need to develop and expand. Policies and schemes implemented to date have provided some indication of what can succeed but they have also been inadequately designed and poorly implemented. It would behove future policymakers to understand the track record of creative industries policy to date and to the return to the vision and recommendations of the DIKN before embarking on new schemes. 


\section{ACKNOWLEDGEMENTS}

This work was supported by the Ministry of Higher Education (Malaysia) under Grant FRGS/1/2014/SS09/UNIM/02/1.

\section{NOTES}

1. According to the 2015 report, only 334 of the 436 (77\%) companies are listed as active.

2. A list of Creative Multimedia status companies can be found at http://www. mscmalaysia.my/status_company.

\section{REFERENCES}

Bernama. 2014. Bajet 2015: RM100 juta untuk majukan industri kreatif. Astroawani, 10 October. http://www.astroawani.com/ (accessed 3 December 2016).

Creative Content Association Malaysia (CCAM). n.d. About us. http://www. creativecontent.my/controllers/public/background (accessed 3 December 2016).

Ch'ng, C. C. 2015. Does Malaysian's animation industry have a future? Penang Monthly, April. http://penangmonthly.com/does-malaysians-animation-industry-have-afuture/ (accessed 3 December 2016).

Creative Industry Lifelong Learning (CILL). n.d. Creative industry lifelong learning progamme. http://cill.my/ (accessed 3 December 2016).

Department of Culture Media and Sport (DCMS). 1998. Creative industries mapping document, 1998. London, UK: Department of Culture, Media and Sport. http://webarchive.nationalarchives.gov.uk/+/http://www.culture.gov.uk/ reference_library/publications/4740.aspx (accessed 3 December 2016).

Economic Transformation Programme. 2013. Creative industry can bloom, if they rise above grant-reliance. 20 November. http://etp.pemandu.gov.my/Related_Stories@ -Creative_industry_can_bloom,_if_they_rise_above_grant-reliance.aspx (accessed 3 December 2016 ).

Ect, E. 2015. Sorry guys, but it's time to bring up U-Wei's "Hanyut" again. Daily Seni, 21 June. http://www.dailyseni.com/v4/sorry-guys-but-we-really-need-to-talk-abouthanyut-again-because-rm18-million/ (accessed 3 December 2016).

Florida, R. 2002. The rise of the creative class: And how it's transforming work, leisure, community and everyday life. New York: Perseus Book Group.

Galloway, S. and S. Dunlop. 2007. A critique of definitions of the cultural and creative industries in public policy. International Journal of Cultural Policy 13(1): 17-31, https://doi.org/10.1080/10286630701201657. 
Hesmondhalgh, D. and A. C. Pratt. 2005. Cultural industries and cultural policy. International Journal of Cultural Policy 11(1): 1-13. https://doi. org/10.1080/10286630500067598.

Ibrahim, A. and C. C. Goh. 1998. Multimedia super corridor. Kuala Lumpur: Leeds.

Iwabuchi, K. 2002. Recentering globalisation: Popular culture and Japanese transnationalism. Durham: Duke University Press. https://doi. org/10.1215/9780822384083.

Kementerian Penerangan Komunikasi dan Kebudayaan. 2009. Dasar industri kreatif negara. www.kkmm.gov.my/pdf/dikn.pdf (accessed 3 December 2016).

King, R. 2008. Kuala Lumpur and Putrajaya: Negotiating urban space in Malaysia, Singapore: NUS Press.

Lee, Y. B. 2014. The art of eating in Malaysian cinema: The Malaysian sinophone hunger for national identity. In Transnational Chinese cinema: Corporeality, desire and the ethics of failure, eds. B. Bergen-Aurand, M. Mazzilli and W. S. Hee, 181-200. New Jersey: Transaction Publishers.

Mahpar, H. 2010. Picture imperfect. The Star, 31 July. http://www.thestar.com.my/ business/business-news/2010/07/31/picture-imperfect/ (accessed 3 December 2016).

Malaysia Today. 2013. Najib not doing what he promised the artistes. 6 November. http://www.malaysia-today.net/najib-not-doing-what-he-promised-the-artistes/ (accessed 3 December 2016).

Malaysian Communications and Multimedia Commission. 2014. Creative industry development fund, Malaysian communications and multimedia commission (CIDF-MCMC). http://www.skmm.gov.my/Content-Development/Overview/ Dana-Pembangunan-Industri-Kreatif-(DPIK-SKMM).aspx (accessed 3 December 2016).

MDEC. 2015. MSC Malaysia annual industry report 2014. http://www.mscmalaysia.my/ sites/default/files/pdf/downloads/2014-MSC-Malaysia-Annual-Industry-Report. pdf (accessed 3 December 2016).

2014. MSC Malaysia annual industry report 2013. http://www.mscmalaysia. my/sites/default/files/pdf/downloads/2013_MSC_Malaysia_Annual_Industry_ Report_FINAL.pdf (accessed 3 December 2016).

MyCreative Ventures. 2014. A boost to local creative industry: MyCreative awards RM21 million funding to 15 successful companies. 17 February. http://www.mycreative. com.my/index.php/corp-comm/press-release/investment-announcement/englishversion (accessed 3 December 2016).

Oakley, K. 2009. The disappearing arts: Creativity and innovation after the creative industries. International Journal of Cultural Policy 15(4): 403-413. https://doi. org/10.1080/10286630902856721.

Peck, J. 2005. Struggling with the creative class. International Journal of Urban and Regional Research 29(4): 740-770. https://doi.org/10.1111/j.1468-2427.2005.00620.x.

PEMANDU. n.d. EPP 1: Nurturing Malaysia's creative content. http://etp.pemandu.gov.my/ Communications,_Content_-\%E2\%97\%98-_Infrastructure-@-Communications Content_and_Infrastructure_-_EPP_1-;_Nurturing_Malaysia_Creative_Content. aspx (accessed 3 December 2016). 
Perbadanan Kemajuan Filem Nasional Malaysia (FINAS). 2014. FINAS: About us. http://www.finas.gov.my/index.php?mod=finas\&sub=pengenalan (accessed 3 December 2016).

Pinewood Iskandar Malaysia Studios. 2014. Pinewood Iskandar Malaysia Studios officially opens and is in full swing. 13 June. http://www.pinewoodgroup.com/our-studios/ malaysia/news/pinewood-iskandar-malaysia-studios-officially-opens-and-fullswing-0 (accessed 3 December 2016).

. 2011. Pinewood Malaysia Studios. http://www.pinewoodgroup.com/our-studios/ malaysia/pinewood-iskandar-malaysia (accessed 20 January 2015).

Rais Yatim. 2011. Dasar industri kreatif negara mampu lonjak ekonomi dan sosio-budaya negara. 23 October. http://www.carigold.com/portal/forums/archive/index. php/t-278062.html (accessed 3 December 2016).

The Star Online. 2014. Hollywood film to be shot in Pinewood Iskandar Malaysia Studios next year. 27 November. http://www.thestar.com.my/news/nation/2014/11/27/ pinewood-iskandar-malaysia-hollywood/ (accessed 3 December 2016).

. 2012. Rais: RM55.5mil boost for creative industry. 20 November. http:// www.thestar.com.my/story $/$ ?file $=\% 2 \mathrm{~F} 2012 \% 2 \mathrm{~F} 11 \% 2 \mathrm{~F} 20 \% 2 \mathrm{~F}$ nation $\%$ 2F12341556\&sec $=$ nation (accessed 3 December 2016).

Unit Perancang Ekonomi. 2013. Wawasan 2020, 1991-2020. http://www.epu.gov.my/ wawasan-2020-1991-2020 (accessed 3 December 2016).

World Intellectual Property Organisation (WIPO). 2008. The economic contribution of copyright-based industries in Malaysia. http://www.wipo.int/export/sites/ www/copyright/en/performance/pdf/econ_contribution_cr_my.pdf (accessed 3 December 2016).

2003. Guide on surveying the economic contribution of the copyright-based industries. http://www.wipo.int/edocs/pubdocs/en/copyright/893/wipo_pub_893. pdf (accessed 3 December 2016). 
